\title{
African biblical hermeneutics and the Book of Ruth: Some observations
}

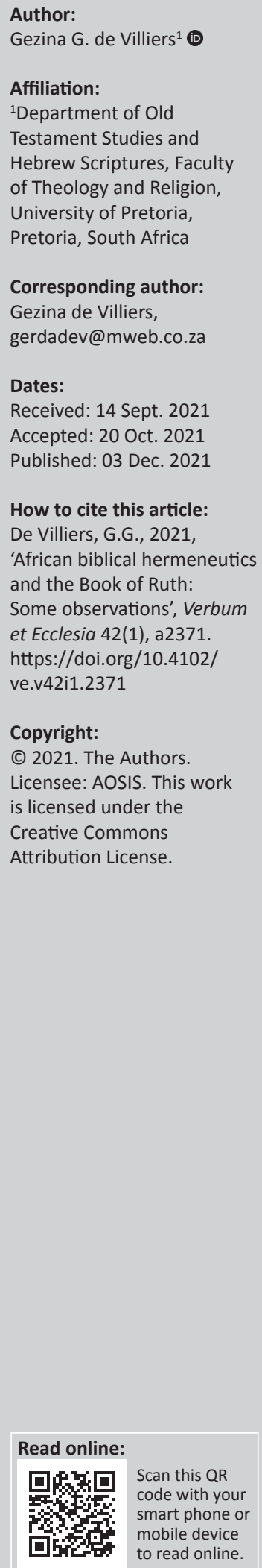

This article investigates interpretations of the Book of Ruth from the point of view of some African scholars. Firstly, an attempt is made to understand what is meant by African biblical hermeneutics $(\mathrm{ABH})$. An overview of the emergence of $\mathrm{ABH}$ is given, and the question why reading the Bible from an African perspective was necessary, is addressed. It appears that African biblical scholars and an African Christian community could not relate to Western European interpretations of the Bible that reflect western experiences and concerns that were vastly different from their own postcolonial experiences and concerns since the latter part of the 20th century.

Intradisciplinary and/or interdisciplinary implications: The engagement between Western and $\mathrm{ABH}$ is discussed, and $\mathrm{ABH}$ as a necessary and viable means of biblical interpretation is recognised, but a point of critique is also raised at the end of this section. Thereafter an overview of $\mathrm{ABH}$ as appropriated to the Book of Ruth is given, and finally, some evaluative conclusions are drawn.

Keywords: African biblical hermeneutics; African biblical studies; Old Testament; Book of Ruth; African scholars; contextual reading; comparative paradigm; comparative methodology.

\section{Introduction}

The topic of this article is 'African biblical hermeneutics and the Book of Ruth'. As a point of orientation, the first part of the article will attempt to understand what is meant by 'African biblical hermeneutics' (ABH). An overview of the emergence of $\mathrm{ABH}$ is given, and the question, why reading the Bible from an African perspective was necessary, is addressed. It appears that African biblical scholars and an African Christian community could not relate to Western European interpretations of the Bible that reflect western experiences and concerns that were vastly different from their own postcolonial experiences and concerns since the latter part of the 20th century. The engagement between Western and $\mathrm{ABH}$ is discussed, and $\mathrm{ABH}$ as a necessary and viable means of biblical interpretation is recognised, but a point of critique is also raised at the end of this section.

The Book of Ruth is chosen as an example to illuminate the differences between a traditional Western European interpretation vis-à-vis interpretations from some African scholars on this book. As an example of Western scholarship, De Villiers (2018:n.p.) proposes that the Book of Ruth was the product of post-exilic scribes who addressed the problem of Israelite identity in the post-exilic Israelite community. Was the 'real Israel' an ethnic community consisting of pure-blood Israelites only as championed by Ezra and Nehemiah, or could non-Israelites be included in an ethic community, that is, foreigners who worshipped $\mathrm{YHWH}$ as the One and Only God and obeyed his commandments. Ruth serves as an example of the latter. As this article examines some African interpretations of the Book of Ruth, it will appear that Israelite identity and the exclusion or inclusion of foreigners in a community are of no concern for African exegetes. The focus is rather on contextual and existential issues in a contemporary situation. These interpretations may serve as an 'eye-opener' to many Western scholars who do not always realise the issues with which African communities are grappling.

Ultimately, one cannot say one hermeneutical approach is better than the other, each has its own place, serves its own purposes, is born from and addresses its own concerns and issues. Hermeneutics is an ongoing endeavour.

Note: Special Collection: African Hermeneutics. 


\section{The emergence of African biblical hermeneutics}

According to the online Oxford Dictionary, the term 'hermeneutics' has to do with 'The branch of knowledge that deals with interpretation, especially of the Bible or literary texts (n.p.). With regard to biblical interpretation, Meenan (2014:268) states that the focus should be on the biblical text and its cultural context that are linked through an 'act of appropriation' to provide an understanding of the bible that may be applicable to its readers. This would imply that such an understanding would resonate with the needs and experiences of a particular community in a real-life situation. Holter (2011:378) then observes that biblical hermeneutics at academic institutions such as universities, followed the Western European approach of the past 2 or 3 centuries ago. This is the case in Christian contexts worldwide, including universities and other academic institutions in Africa. Since the latter part of the 20th century, it became increasingly clear that Western European biblical hermeneutics does not address the concerns of African biblical readers, and therefore, African biblical scholars started to develop and employ interpretative strategies for African Christian communities.

However, this is no simple endeavour for it is not always clear what is meant by 'African': Africa is a large continent with many and varied African traditions. African biblical scholars who study theology and biblical studies at academic institutions in Africa are not only instructed in a Western European hermeneutical approach, but they would also follow the tradition of the previous colonial powers in their country. Holter (2011:380) and Mbuvi (2017:151) both observe distinctive hermeneutical approaches between Anglophone Africa that follows the English tradition and Francophone Africa that follows the French tradition. Mbuvi (2017:151) also adds the Lusophone or Portuguese tradition. Nevertheless, despite these differences, African biblical scholars seem to share the same ambition, namely to devise hermeneutical strategies that would appeal to an African context.

Consequently, some distinct features of $\mathrm{ABH}$ will be discussed. Adamo (2015:34) from Africa and Mbuvi (2017:149) from the USA both observe the impact that white colonialisation had on black communities. Adamo points out the negative consequences of colonialisation on the indigenous African population in several ways. He exposes the ways in which Bible was used as a legitimate tool to oppress and to marginalise, and to denigrate and degrade the culture and belief systems of Africans, to lower class and superstition. Africans were converted to Christianity, but this was the Christianity of the colonisers, thus Eurocentric by nature. As Holter (2011:378) also observed, African biblical scholars who sought further theological education were inevitably trained at Eurocentric tertiary institutions where the Bible was read and understood in a de-Africanised way. This was not deliberate; it was just the conventional and traditional way teaching biblical hermeneutics at the time. Thus, one of the main tasks of $\mathrm{ABH}$ is to take away these colonial and Eurocentric hermeneutics and reinterpret the Bible for Africa.

By dismissing the Western intellectual ideas and concepts, $\mathrm{ABH}$ can embark on a process that begins to 'put back' an African understanding of the bible in an African context to which Africans can relate within their own cultural experiences. Recognition of and respect for African identity and culture would promote a reading of the Bible from an African point of view, and consequently, reshape ideas according to indigenous custom and local needs. In this regard, Adamo (2015:35-36) refers to what he calls 'Blackening the Bible' which he considers to be 'true Africentricism', that is, placing Africa at the centre of biblical investigation. The world of the Bible is seen from an African perspective that enables scholars to construct a hermeneutics to which everyday Africans can relate. Included in such a hermeneutics is an existential interpretation of the Bible, for the Bible also addresses the everyday needs and experiences of ordinary people.

At this point, almost between brackets as it were, a point of critique may be raised with regard to Adamo's article. It was published in 2015, and one may question whether he is perhaps too idealistic with his suggestion that all colonial, European and Western influences can be removed from an African identity. The African continent is nowadays part of and connected to the global world via the latest technology various electronic devices, Internet access and cell phones are as much part of African life as elsewhere in the world. Africans also emphasise literacy and education, they partake in the corporate world and contribute to the economics of society, some African women are skilled in various professions and some of them are fully emancipated and no longer accept the patriarchal domination of traditional tribal life.

Furthermore, Adamo's accusation that ABH protests against a 'Western' or 'European' hermeneutics that also advocates a Western-European culture may have been the case during the times of colonialisation but is no longer so. The aim of 'European hermeneutics' (if I may call it so) is first and foremost to understand the context of the text. De Villiers (2019:5-6) points out numerous works on the Book of Ruth - commentaries and articles - by Austrian and German scholars whose first endeavours were to understand the context of the Book: when was it written, and why was it written? What were the questions in that particular context, and which answers did the biblical authors provide? Thus, where $\mathrm{ABH}$ engages with the text from an African perspective as Adamo (2015:35-36) suggests, the centre of 'European hermeneutics' is to take the context of the text as point of departure. Nevertheless, the aim of this article is to embrace the contributions of $\mathrm{ABH}$, keeping in mind that there are several other hermeneutic approaches that are equally valid (De Villiers 2019:1-7).

Continuing the discourse on ABH, Mbuvi (2017:149), in discussing the emergence of African biblical studies (ABS) has observations that are similar to those of Adamo, discussed 
above (Adamo 2015:34-35). He describes such endeavours that is, to develop ABS or ABH - as both 'innovative' and 'reactionary'. These attempts are 'innovative' in the sense that they are not restricted to Western European methodologies and assumptions that dominate biblical studies, but instead they develop biblical interpretation in a way that is relevant to present concerns. At the same time, they are also 'reactionary' because they expose the inadequacy of Western hermeneutics to respond to the needs of African communities.

Although the biblical text is the focus and constant factor in hermeneutics, Meenan (2014:268) points out that it does not exist in a vacuum, and the text is received by a particular audience within a particular cultural context. In other words, there is a dialogue between the texts and its readers. With regard to Old Testament Studies at higher educational institutions in Africa, Holter (2011:381) noted an increasing demand that these studies focus on 'African experiences and concerns as interpretative recourses'. Here, the dialogue takes place as a direct encounter between Africa and the Old Testament which has led to a development known as a 'comparative paradigm'. What happens is that a wide spectrum of Old Testament texts and concepts are explicitly compared with African experiences and concerns that seem to correspond to the text (Holter 2011:381). Such a 'comparative methodology' is also noted by Meenan (2014:368) where the emotions or situation of a biblical text is compared with similar, or supposedly similar circumstancesin an African context. Acomparativemethodology '... acilitates a parallel interpretation of certain biblical texts or motifs abd supposed African parallels, letting the two illuminate one another' (Meenan 2014:368).

Both $\mathrm{ABS}$ and $\mathrm{ABH}$ emphasise a close engagement between the biblical texts and the African context, and that biblical studies are not reserved for academic purposes only, but are the privileges of all readers alike, academics and ordinary people. Therefore, $\mathrm{ABH}$ involves the whole community in its understanding of the Bible - non-scholars, the poor, the marginalised, also referred as 'contextual readers', and a 'contextual reading of the Bible' which paves the way to an uncritical and immediate interpretation of Scripture. This, according to Adamo (2015:36) is a distinctive feature of $\mathrm{ABH}$.

In the introductory chapter of their book, Navigating African Biblical Hermeneutics $(A B H)$. Trends and Themes from our Pots and our Calabashes, the editors Masenya (Ngwan'a Mphahlele) and Ngwa (eds. 2018) observe that technology, where they state that:

\footnotetext{
... $\mathrm{ABH}$ has forged its identity and methodology not just in resistance to the punctual acts and enduring legacies of colonialism, cultural imperialism, global capitalism and apartheid; it has also forged its identity and methodology in conjunction with its own cultural and technological renaissance .... (p. 1)
}

But it is not exactly clear what is meant by this cultural and technological renaissance. Further, they agree completely with Adamo that the interpretations of colonial and imperial missionary enterprises must be eliminated from $\mathrm{ABH}$, and they add that in addressing contemporary issues of politics and power, gender inequality and patriarchy, economic exploitation and social injustice, $\mathrm{ABH}$ becomes transformative and liberative and contributes to the well-being of society (eds. Masenya [Ngwan'a Mphahlele] \& Ngwa 2018:4).

Thus, the interest of $\mathrm{ABH}$ seems to be in the interaction between Africa's contextual concerns with the Bible. From Masenya (Ngwan'a Mphahlele) and Ngwa's introduction, the role of the biblical context is not clear. Of course, the Bible is read - but is the context of the biblical text considered, or is the ancient context simply placed next to the African one to derive at some interpretation? In this regard, $\mathrm{ABH}$ may take note of Meenan's (2014) critique:

The problem facing the church in Africa today is a distinct lack or ability to hear the text, first in its original Sitz in Leben, its own socia-historical context, and then second, in its consideration of the writer's intent, and third, in its unbiased approach to the African contxt and, in a larger sphere, to the world. African scholars are often eclectic in their approach and the ideotheological orientation of a particular biblical interpreter tends to define the focal of analysis. (p. 271)

In the discussion of ABH and the Book of Ruth below, Meenan's observations will appear to be significant.

\section{African biblical hermeneutics and the Book of Ruth}

In 2010, Madipoane Masenya (Ngwan'a Mphahlele) writes an article with the title: 'Is Ruth the 'ěšethayil for real? An exploration of womanhood from African proverbs to the threshing floor (Rt 3:1-13)'. ${ }^{1}$ The question that Masenya (Ngwan'a Mphahlele) addresses is what is meant, or what can be understood by the expression, 'a worthy woman'. In the biblical text of Ruth 3:11, what did Boaz mean when he called Ruth an 'éšthayil, and what - or who - is a 'worthy woman' in contemporary African cultures? Masenya (Ngwan'a Mphahlele) observes the changing of times, also in traditional African societies. Traditionally, most, if not all women would opt for a heterosexual marriage and consequently bearing children; however, nowadays women may choose for education, with or without a heterosexual marriage, with or without children (Masenya [Ngwan'a Mphahlele] 2010:1-2). However, such life-affirming choices (from women) are often obstructed by biblical texts, for biblical narratives are always informed by the viewpoint, agenda and ideologies of the biblical authors, usually male. This is also the case in the Book of Ruth: she is called an 'éšethayil by Boaz and by implication reflects the narrator's ideas of what a 'worthy woman' is.

Masenya (Ngwan'a Mphahlele) proceeds to examine images of womanhood in some African proverbs to determine to which extent they resonate with the biblical text and concur with images of women who seek to find their identities within the 1.References to this article will be according to online page numbers. 
African culture and the Bible (Masenya [Ngwan'a Mphahlele] 2010:4-10). She covers a wide spectrum of diverse African traditions, and it appears that in all of them, the 'worthy woman' is associated with heterosexual marriage, motherhood and children. Returning to the biblical text, she then states:

This usage of the Hebrew words 'îššah to refer to both woman and wife reminds us of the word mosadi (woman) in the Northern Sotho African South African culture and how its usage in some proverbs equated every mosadi with a married woman! (p. 11)

Thus, when Boaz praises Ruth as an 'ēšethayil, he (and the biblical narrator) can only have her marital status and childbearing potential in mind (Masenya [Ngwan'a Mphahlele] 2010:12). She concludes that:

The preceding discussion has hopefully revealed that definitions of womanhood, as prescribed by African proverbs as well as the text of Ruth 3, are restrictive and thus not always affirming to those women who choose to define the worthiness of their womanhood outside of the categories of heterosexual marriage, childbearing, and childrearing. It makes sense, though it is not acceptable, that on account of the patriarchal nature of the post-colonial, post-independence, post-apartheid African contexts in which we are located, such definitions continue to be entrenched. They continue to reign supreme in our families and in our ecclesiastical settings, also sanctioned through the employ of texts such as the Book of Ruth as being God-ordained! (p. 17)

In the light of such proverbs and such biblical texts, questions need to be asked by all those (especially women) who wish to pursue 'affirming, life-enhancing definitions of what it means to be a "worthy woman" in an African context' (Masenya [Ngwan'a Mphahlele] 2010:18).

Another article of Masenya (Ngwan'a Mphahlele) appears in 2013, this time with the title, 'Engaging with the book of Ruth as single, African Christian women: One African woman's reflection' (Masenya [Ngwan'a Mphahlele] 2013:1-9). This time Masenya (Ngwan'a Mphahlele) chooses a rural traditional African storytelling background for the (re)telling of the Ruth narrative from an African perspective. The storyteller is her grandmother - either real or fictitious whose praise name is Moremadi. Moremadi interprets the narrative in terms of her own culture and enhances her understanding with appropriate African proverbs. However, she finds Ruth 3 rather disturbing. It exposes the vulnerability of women, the need for women to use their bodies for security, the possibility for sexual abuse of women by men in power, and prostitution amongst other things. Narratives like these have the possibility to deny women of living her life to the full (Masenya [Ngwan'a Mphahlele] 2013:3).

Masenya (Ngwan'a Mphahlele) (2013:4) further observes that heterosexual marriages and bearing children appear to be normative in both cultures - the biblical and the African. Would a heterosexual marriage be the only option for single women or poor young widows to solve their problem? And what about older widows and same gender loving women? The biblical narrative does not address this issue. Thus, the second part of the article is a communal reading with women who have the experience of being single (Masenya [Ngwan'a
Mphahlele] 2013:5-9) to determine to which extent they could relate to the character of Ruth, to explore practical ways of dealing with sexual challenges in the absence of men, and so on. The main purpose of the interviews was to find out whether the Ruth narrative could be helpful or not for a single woman living in 21st century. The responses varied, but it appears that $80 \%$ responded positive to the Ruth narrative, albeit not directly (e.g. the relationship between Ruth and Naomi may set an example for same-gender relationships [Masenya (Ngwan'a Mphahlele) 2013:8]). Nevertheless, there are still many unanswered questions. In her conclusion, Masenya (Ngwan'a Mphahlele) (2013:9) suggests that each and every one should be committed to address the plight of the needy in society, thereby becoming a go'el of substance.

Human immunodeficiency virus (HIV) and acquired immunodeficiency syndrome (AIDS) continues to be a serious health issue in South Africa, and this problem is addressed by Gerald West and Beverley Haddad in their article 'Boaz as "sugar-daddy": Re-reading Ruth in the Context of HIV in Southern Africa'. The article starts with some newspaper quotations, either from 'sugardaddies' (older men) requesting (mostly sexual) services of 'sugarbabies' (younger women) who will be amply compensated, or from young women who offer their (mostly sexual) skills to rich older men (West \& Haddad 2016:138-139). Consequently, shocking statistics are provided with regard to the incidence rate of HIV cases in South Africa. This was in 2016. One shudders to imagine what it is like in 2021.

West and Haddad (2016:142) observe that young women who engage in sexual relationships with older men are more prone to contract HIV than when having sex with men of their own age for reasons that are not yet fully understood. However, the causes for young women seeking 'sugardaddies' become apparent. Poverty and basic material need and lack of sufficient fees to pay for education drive young girls from both rural and urban areas to offer their bodies and sex for older men in their search for socio-economic stability. City girls would also seek the glitz, glamour, fun and show-off that only money can provide. These girls are not victims, but the active instigators luring rich older men into the pleasures they may have to offer (West \& Hadad 2016:144-145).

To address the problems of HIV and disparate sex relationships between older men and younger women, West and Haddad conduct a contextual Bible study where they turn to the Book of Ruth as an obvious example for such a relationship. ${ }^{2}$ Their group consists of vulnerable young women, and they ask literary questions regarding the Ruth narrative questioning inter alia the motives of Boaz, Ruth and Naomi in the development of the plot and, of course, whether Boaz can be regarded as a 'sugardaddy' (West \& Haddad 2016:152-154). Their final question is Question 10: 'What social and theological structures must we engage with to address the 'sugar daddy' situation? What from your perspective needs to change?' (West \& Haddad 2016:155), and in conclusion they express their expectations of active

2.The assumption that Boaz was much older than Ruth is common but is nowhere indicated directly in the text itself. 
intervention and HIV prevention programmes to address the role of the 'sugar daddy' in this regard.

The article of Mtshiselwa (2016:1-5) sees parallels between landless poor women in South Africa and the biblical texts of Ruth 4 and Leviticus 25:8-55. The two biblical texts indicate that women could neither own property in the ancient world, nor could they benefit from the produce of land, unless they were related to a male figure, and in present day, postapartheid South Africa, the situation is no different for poor women, he argues. Both texts expose: patriarchy; a majority of landless and poor women; women 'relegated to being working class citizens without productive land'; in contrast to most poor landless women, a minority of men happen to have access to land (Mtshiselwa 2016:4). These texts are oppressive and do not provide liberating possibilities for poor, landless women. To address this problem, Mtshiselwa (2016:4-5) appropriates the hermeneutical approach of Fernando F. Segovia and the ideologies of Ernesto 'Che' Guevara' on the ancient texts and the situation in South Africa and points out the implications.

Segovia acknowledges the 'otherness' if the biblical world, but also its concern with common human issues like economic and political questions, gender, social structures, and so on. With regard to the situation in South Africa, Segovia's observations would imply a consciousness and awareness that landlessness and poverty of women are a tragic reality. These observations may provide liberating possibilities. Guevara would go further and encourage an agrarian revolutionary protest, perhaps involving violence, if necessary (Mtshiselwa 2016:4-5). Mtshiselwa himself does not propose violence, but rather suggest a 'peaceful protest' against a system that upholds patriarchy, poverty and prevents women from owning land (Mtshiselwa 2016:4-5).

In a recent publication, Odo (2021:1-7) provides a more positive interpretation of the Book of Ruth. His focus is Ruth 1:16-18 - Ruth's famous speech to her mother-in-law and her vow that she will cling to her until death will part them. Odo (2021:2) does pay attention to the context or Sitz im Leben of the Book of Ruth and agrees that it can be dated to the postexilic period when Israel was struggling with an identity crisis: should foreigners be accepted in the Israelite postexilic community or not? The Book of Ruth argues against authors of books like Ezra and Nehemia who advocate an exclusive ethnic Israelite community, by reminding the Israelites that God's loving kindness also extends to non-Israelite foreigners.

Odo (2021:4-7) then appropriates the text of Ruth 1:16-18 to the Igbo people in southern Nigeria and focuses especially on mother-in-law and daughter-in-law relationships. He observes that contrary to the loving and caring relationship between Ruth and Naomi, in-law relationships between elder and younger women are often troublesome and strained. After marriage a woman moves to her husband's family where she is placed under the authority of her mother- in-law. The mother-in-law is expected to guide the younger women and give her good advice; in turn, the daughter-inlaw should show respect to the elder woman and aid her in all sorts of chores. Unfortunately, good relationships and traditional family structures were disturbed by civilisation and modernity (Odo 2021:5). In contemporary Igbo culture, often mothers-in-law make life miserable for their daughtersin-law who on their part show no respect for the elder women. Odo (2021:6) thus suggests that the example of mutual steadfast love and caring set by Ruth and Naomi should be followed by mothers- and daughters-in-law also in modern-day Igboland.

\section{Evaluative conclusion}

Except for the contribution of Odo, the rest of the articles indicate that the narrative of Ruth does not have much liberating and transformative possibilities when read and interpreted in terms of $\mathrm{ABH}$. The narrative is invested with patriarchy and proposes that women can only be fulfilled by means of a heterosexual marriage and progeny. On a darker side, there are indications that women may have to use their bodies, if necessary, to achieve this goal, especially if they are poor and desperate. Only if these oppressive elements in the text are exposed, liberating possibilities may emerge. Patriarchy, poverty, the suppression and exploitation of women, social injustice, gender discrimination and so forth are tragic realities, not only in the ancient world but also in contemporary societies of the 21st century. Scholars using $\mathrm{ABH}$ exposed this clearly, not only in their readings of the Book of Ruth, but also in their readings of other biblical texts.

In her article 'Interpreting texts and the matter of context. Examples from the Book of Ruth', De Villiers (2019:1-7) discusses various hermeneutical approaches to the Book of Ruth and points out the pros and cons of each interpretation. She emphasises that no reading or interpretation of the text can be regarded as 'more correct' or 'better' than the other. Every text is open to multiple and varied interpretations, and the immediate context and concerns of the exegete play a major role. And with regard to $\mathrm{ABH}$ this is very important. Real issues within traditional African communities appear to be patriarchy, poverty and the oppression of women. African biblical hermeneutics, and especially its engagement with real readers in a pre-critical and immediate encounter with the test, is illuminative within the South African and African context. This certainly is the strong point and distinctive feature of ABH as Adamo (2015:36) observes.

Ultimately, $\mathrm{ABH}$ alerts every exegete, no matter which hermeneutical approach she or he follows, to be extremely sensitive to her or his immediate context and to address the needs and concerns of everyday people in everyday situations. It serves at a reminder that hermeneutics should refrain from being an academic enterprise only, and as much as it seeks to interpret the Bible, so much it should also seek to interpret the Bible for all communities. 


\section{Acknowledgements Competing interests}

The author declares that she has no financial or personal relationships that may have inappropriately influenced her in writing this article.

\section{Author's contributions}

G.G.d.V. is the sole author of this article.

\section{Ethical considerations}

This article followed all ethical standards for research without direct contact with human or animal subjects.

\section{Funding information}

This research received no specific grant from any funding agency in the public, commercial or not-for-profit sectors.

\section{Data availability}

Data sharing is not applicable to this article as no new data were created or analysed in this study.

\section{Disclaimer}

The views and opinions expressed in this article are those of the author and do not necessarily reflect the official policy or position of any affiliated agency of the author.

\section{References}

Adamo, D.T., 2015, 'The task and distinctiveness of African biblical hermeneutic(s)', OTE 28(1), 31-52. https://doi.org/10.17159/2312-3621/ 2015/v28n1a4

De Villiers, G., 2018, 'The Pentateuch and its reception in the Book of Ruth: Constructing Israelite identity', Journal for Semitics $27(1)$, n.p. https://doi. org/10.25159/1013-8471/3358

De Villiers, G., 2019, 'Interpreting texts and the matter of context: Examples from the Book of Ruth', Verbum et Ecclesia 40(1), 1-7. https://doi.org/10.4102/ve. v40i1.1925

Holter, K., 2011, 'The role of historical-critical methodology in African Old Testament studies', Old Testament Essays 24(2), 377-398.

Masenya (Ngwan'a Mphahlele), M., 'Is Ruth the 'êšethayil for real? An exploration of womanhood from African proverbs to the threshing floor (Ruth 3:1-13)', Studia Historiae Ecclesiasticae 36(S1), 253-272.

Masenya (Ngwan'a Mphahlele), M., 2013, 'Engaging with the book of Ruth as single, African Christian women. One African woman's reflection', Verbum et Ecclesia 34(1), 1-9. https://doi.org/10.4102/ve.v34i1.771

Masenya (Ngwan'a Mphahlele), M. \& Ngwa, K.N. (eds.), 2018, 'Introduction', in Navigating African biblical hermeneutics $(A B H)$ trends and themes from our Pots and our calabashes, pp. 1-19, Cambridge Scholars Publishing, Newcastle upon Tyne.

Mbuvi, A., 2017, 'African biblical studies: An introduction to an emerging discipline', Currents in Biblical Research 15(2), 149-178. https://doi.org/10. $1177 / 1476993 \times 16648813$

Meenan, A.J., 2014, 'Biblical hermeneutics in an African context', The Journal of Inductive Biblical Studies 1(2), 268-273.

Mtshiselwa, V.N.N., 2016, 'Reading Ruth 4 and Leviticus 25:8-55 in the light of the landless and poor women in South Africa: A conversation with Fernando F. Segovia and Ernesto "Che" Guevara', HTS Teologiese Studies/Theological Studies 72(1), a3140. https://doi.org/10.4102/hts.v72i1.3140

Odo, D.O., 2021, 'Exploring Ruth 1:16-18 in the context of mother and daughter-inlaw relationships in Igboland', Verbum et Ecclesia 42(1), a2213. https://doi. org/10.4102/ve.v42i1.2213

West, G.O. \& Haddad, B.G., 2016, 'Boaz as "sugar-daddy": Re-reading Ruth in the context of HIV in Southern Africa', Journal of Theology for Southern Africa 155(special issue), 137-156, viewed n.d., from https://africafaith.org.za/wpcontent/uploads/2018/07/13-WestHaddadBoazRuthHIV.pdf.

Online Oxford Dictionary, Hermeneutics, viewed n.d, from https://www. oxfordreference.com/view/10.1093/oi/authority.20110803095932785. 